\title{
State-of-Art Functional Biomaterials for Tissue Engineering
}

\begin{abstract}
Krati Sharma ${ }^{1}$, Mubarak A. Mujawar ${ }^{2}$ and Ajeet Kaushik ${ }^{3,4 *}$
${ }^{1}$ Department of Biology, Temple University, Philadelphia, PA, United States, ${ }^{2}$ Department of Electrical Engineering and Computing, Florida International University, Miami, FL, United States, ${ }^{3}$ Department of Immunology and Nano-Medicine, Center for Personalized Nanomedicine, Institute for Neuroimmune Pharmacology, Herbert Wertheim College of Medicine, Florida International University, Miami, FL, United States, ${ }^{4}$ Department of Natural Sciences, Division of Sciences, Arts \& Mathematics, Florida Polytechnic University, Lakeland, FL, United States
\end{abstract}

Nanobiotechnology-enabled tissue engineering strategies have emerged as an innovative and promising technique in the field of regenerative medical science. The design and development of multifunctional smart biomaterials compatible to human physiology is crucial to achieve the required biological function with a reduced negative biological response. Several medical bioimplants have been tested to boost life expectancy and better-quality life. The concept of biocompatibility focuses on body acceptance and no harmful effects after implantation, which require shaping the properties of materials synthesis, surface functionalization, and biofunctionality. Such developed bioactive and biodegradable materials have been utilized to achieve the required function at a specific period and sustainability to withstand the surrounding tissues for treating severe injuries and diseases. Thus, exploring new approaches to design multifunctional biocompatible advanced nanostructures to develop next-generation therapies for tissue engineering, this mini-review is an attempt to summarize the advancements in biofunctional smart materials. The review focuses on bio-mimic materials, biomaterials, self-assembly biomaterials, bioprinting functional hydrogels, new polymeric architectures, and hybrid synthetic-natural hydrogels in the field of tissue engineering and regenerative medicine (TERM). This mini-review will serve as a guideline to design future research where the selection of a smart multifunctional biomaterial is crucial to obtain best TERM performance.

Keywords: nano-bio-technology, smart materials, biomedical applications, tissue engineering, functional biomaterials

\section{INTRODUCTION}

Body tissues possess a highly organized structure and unique composition that help in providing mechanical and transport support to regulate biological and cellular function. Owing to tissue injury, disease, malfunctioning, or aging, there is a need for natural biodegradable, and biocompatible materials that can be mimicked to actual tissue architecture and structural organization. These tissue-engineered constructs can be helpful in restoring and repairing malfunctioned tissues and organs at the high social and economic point of view (WHO Scientific Group, 2003; Kang et al., 2015). It is challenging to incorporate these bioengineered materials due to limitations of onsite target and side effects such as cell toxicity, interfering with immune systems, and transporting mechanisms. Also, designing and developing a system based on biological features such as mechanical stress at the targeted site, strength, complex viscoelastic, nonlinear, and anisotropic mechanical features have constantly been an area of consideration, as illustrated in Figure 1. 
The above-mentioned features further vary based on physiology affecting factors such as age, site, etc., in the human body. Highly specialized structures with the well-interconnected network should be maintained by newly designed tissueengineered constructs. The basic type of biomaterials can be synthetic polymers, such as polyanhydrides, and naturally occurring polymers, such as complex sugars (hyaluronan and chitosan), and other inorganics (hydroxyapatite). They are also classified based on functions such as hydrogels (Rosamond et al., 2007), injectables (Baroli, 2007), capable of drug delivery (Singh et al., 2015), and surface modified (Chung and Park, 2007; Ma et al., 2007), and by other specific features. Without improper mimicking of highly organized architectures of tissues and organs, channelizing an adequate amount of nutrient transfer, oxygen transport, and other biological function can be critical. Hence, advance biomaterials are important in the emerging role of tissue engineering (TE), and it is mandatory to have deep knowledge about the targeted site. Biomaterial quality also depends on the mode of application such as injectable, in vivo implantation or minimally invasive procedure, the effect of bioactive molecules that might be released, activated immune cascade or signaling pathways, etc.

Considering trends, challenges, and demand in mind, our focus in this mini-review article is to discuss state-of-the-art advanced functional biomaterials in cardiac/heart valve TE, pancreas TE, orthopedic interface TE, thick and vascular celltype TE, and implants for other growth factors. The challenges, prospects, and viewpoint of authors are also presented in this report.

\section{CARDIAC TE}

Failure of cardiac muscles (CMs) is typically due to lack in self-regenerative capacity, impaired contractility, and abnormal stress distribution. Restoring CM's function or malfunctioning of heart valves require innovative strategies to create living heart valves, and regain heart muscle function. Never-resting CMs require robust mechanical strength to contract continuously and efficiently over the $3 \times 10^{9}$ cardiac cycles of an average human lifetime. Mimicking three-dimensional (3D) architecture of collagen networks such as distinct endomysia (Domb and Mikos, 2007), perimysia (Macchiarelli et al., 2002), and epimysia is the most challenging parameter in cardiac TE. Several strategies are being developed to restore CM functions using various cell sources, scaffold types, and fabrication methods (Figure 2A). The foremost features toward cardiac TE are mimicking, enduring contraction of cardiac tissue without surrendering to mechanical failure, and allowing infiltration of cells within the matrix (Pope et al., 2008). The most utilized biomaterials are extracellular matrix (ECM) proteins (Zimmermann et al., 2002; Kutschka et al., 2006), natural biomaterials (Christman et al., 2004; Zimmermann et al., 2004; Reis et al., 2012), and synthetic biomaterials (Kraehenbuehl et al., 2008; Fujimoto et al., 2009; So et al., 2009) to mimic stem cell differentiation (Kharaziha et al., 2016).

Nanomaterials such as carbon nanotubes (CNTs) (Martinelli et al., 2012; Patel et al., 2016), gold (Au) nanorods (Fleischer et al., 2014; Navaei et al., 2016, 2017; Shin et al., 2016), graphene oxide (GO) nanoflakes (Shevach et al., 2013; Park et al., 2015a), silicon nanowires (Park et al., 2015b; Tan et al., 2017), and iron oxide (Han et al., 2015; Richards et al., 2016) in conjugation with the extracellular and intercellular microenvironments of transplanted cells are believed to enable regeneration of injured CMs (Singh et al., 2014; Amezcua et al., 2016; Mehrali et al., 2017). Regenerative properties of CMs can be measured by obtaining electrical conductivity, protein adsorption affinity, intracellular signaling pathways, and magnetic properties. Carbon-based nanomaterials have high electrical conductivity, nanoscaling features, and high affinity for physicochemical interactions with proteins and other functional compounds (Patel et al., 2016). Further, integrating CNTs with glass-based substrates shows higher growth rate, metabolic activity, and better proliferation capacity (Kojima et al., 1990; Huynh et al., 1992; Cerbai et al., 1999). More studies based on the same system found that maturity of CMs is directly associated with the expression level of cardiac-specific genes.

GO is good for constructs, which need strong physiochemical interactions such as covalent, electrostatic, and hydrogen
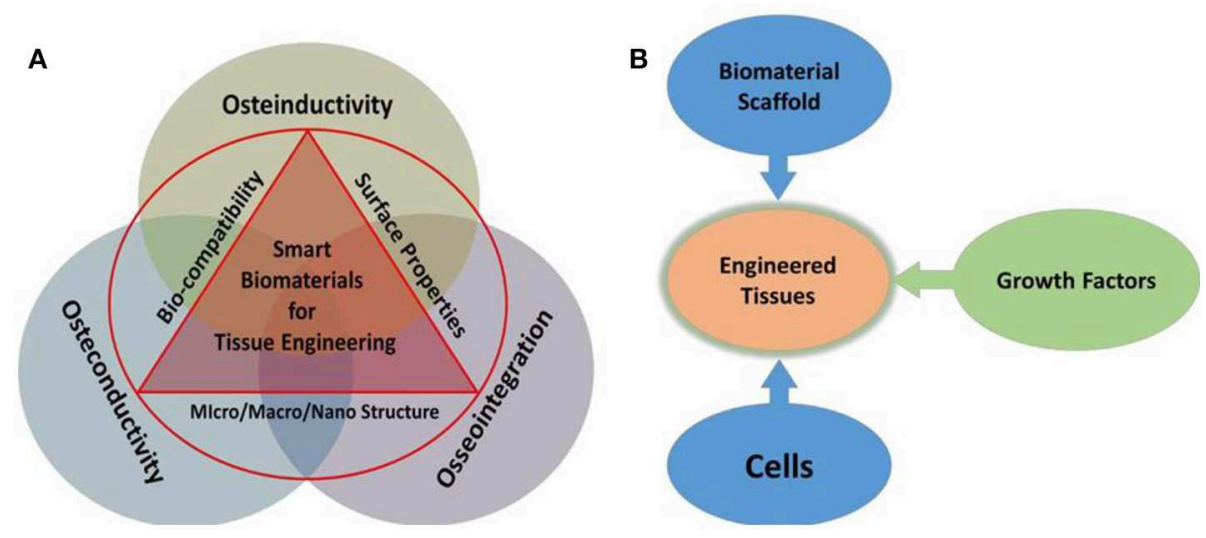

FIGURE 1 | Illustration of salient features of biomaterials required for TE (A), and combination of biomaterials, cell, and growth factors (signaling) associated with tissue engineering (B) depicts integration of smart biomaterials with specific salient features, which facilitate osteo function and regulation. 

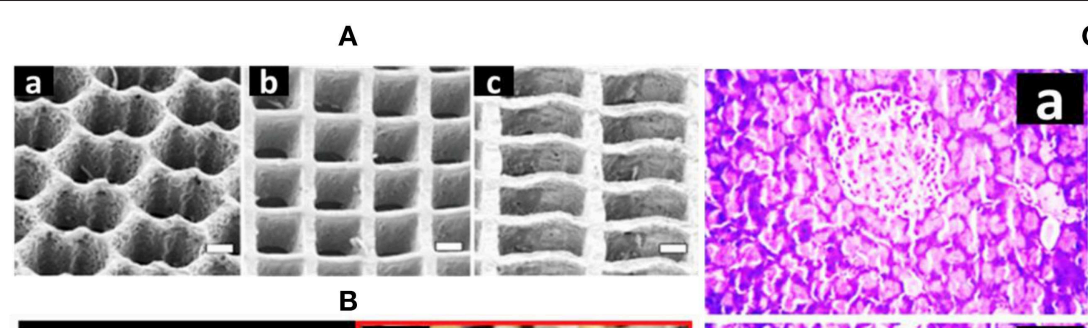

C
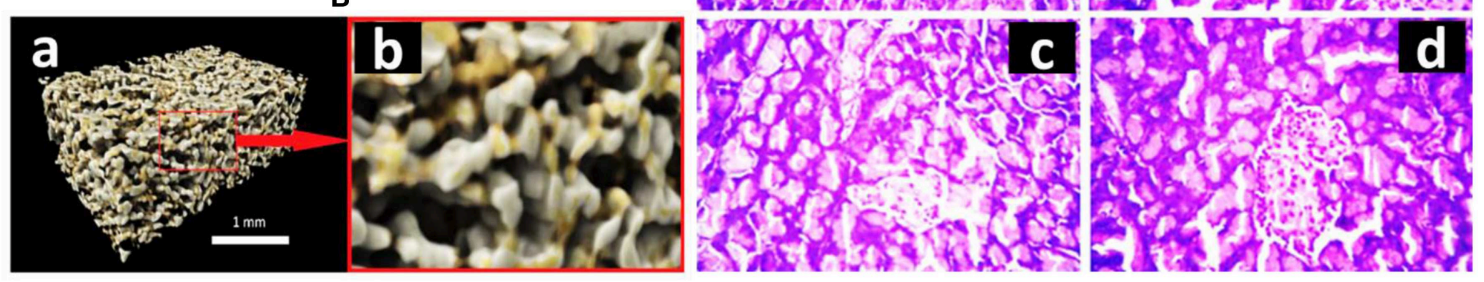

FIGURE 2 | (A) Three synthetic 3D scaffolds in different shapes: a honeycomb, a square, and a rectangle (adopted from Engelmayr et al., 2008). (B) Computer-rendered images of composite scaffold showing (a) a porous structure of the scaffold in 3D and (b) a zoomed section to better display the pore network (1 mm across) (adopted from Hatton et al., 2019). (C) Histopathology examination of pancreas sections - (a) normal pancreas, (b) diabetic pancreas, (c) silybin (Sb)-treated pancreas, (d) Sb nanoparticle-treated pancreas (adopted from Das et al., 2014).

bonding and higher surface area (Li et al., 2016). GO nanofilms are cell-adhesive components and have been seen preventing cell apoptosis because of limited cell-ECM interactions (Chiarugi and Giannoni, 2008; Shi et al., 2012). On the contrary, reduced GO nanofilms improved cell-ECM interactions due to high electrical conductivity, which enhances $\beta 1$ integrin expression. Silicon nanowires with self-assembled humaninduced pluripotent stem cell increased homogenous expressions of intercellular adherents ( $\mathrm{N}$-cadherin) and $\mathrm{Cx} 43$ gap junction proteins (Tan et al., 2017). Iron oxide with rat myoblasts shows a variety of improvements including upregulation of $\mathrm{Cx} 43$ in mesenchymal stem cells (MSCs) and angiogenic markers (Han et al., 2015). Hence, to offer a scaffold close to nativelike cells is mandatory for successfully engineered tissue. Cell toxicity and biocompatibility have always been a controversial issue. Moreover, the distribution profile of nanomaterials within engineered tissues is unknown. Another major concern is the site of administration where the nanomaterials may affect physiological response on endocytosis. Hence, having a scaffold nearly like a native structure is a major step toward TE. The use of biological molecules such as ECM proteins and synthetic biomaterials can be effective for controlled stem cell differentiation. However, these biomaterials are in limited use due to lack of electrical conductivity and nanotopographic features within the biomaterials.

Many studies based on the scaffold design including 3D scaffolds are under investigation. One study aimed to design a 3D scaffold composed of poly(vinyl) alcohol (PVA) fabricated using gas foaming and freeze-drying processes without requiring crosslinking agents. This forms a biocompatible matric with strong stress-strain curves of the PVA scaffolds with expected elastic behavior as of ECM of muscles (Sarker et al., 2014). Decellularized cells were integrated, which helped in improving limitations with transport. The scaffold was prepared using decellularized heart cells from a rat with $1 \%$ sodium dodecyl sulfate (SDS). This maintained myocardial ECM structure and blood vessels. Further, perforation was done using electric stimulation, which restored nascent pump function $(2 \%$ of adult heart rate) (Zimmermann et al., 2006; Dattola et al., 2019). Another work explained honeycomb-like materials with hexagonal-shaped wax to balance the mechanical properties (Polo-Corrales et al., 2014). Several honeycomb-like structures were used in native myocardium including endomysial sheaths and interconnecting CM fibers (Shapiro and Cohen, 1997). Some studies have incorporated PGS [poly(glycerol sebacate)] with honeycomb structures, which improved oxygen-carrying capacity (Zmora et al., 2002). PGS foams with laser-perforated flow channels were ingested into neonatal rat heart cells. The system further involved perfluorocarbons in a culture medium to increase oxygen transportation (Zmora et al., 2002). Various natural and synthetic poly-materials have been tested along with "scaffold-less" approaches, which have been under review (Eschenhagen and Zimmermann, 2005; Furuta et al., 2006). One study demonstrated improved left ventricular function after implanting heart cells embedded in a mixture of type 1 collagen gel and matrigel in rat (Khademhosseini et al., 2007). However, this raises many limitations related to mechanical weakness of collagen gels and foams, and bring the clinical application in doubt. Conventional TE was shown to have successful approaches, but they still have certain limitations. Most importantly, fabrication of full functional construct to regenerate defected cells is important to understand. 3D printed scaffold and 3D bioprinting technique have potential to develop fully functional heart construct.

\section{BONE TE}

Bone TE equips the best combination of biomaterials with biodegradable polymers to support the existing state of bone tissue structure or to enable bone tissue growth. Surface 
modification plays a key role to hold tissue-implant interface regenerated structure against stress and strain imbalance. Poor integration of orthopedic implants can lead to loosening of bioimplants, malfunctioning, and permanent failure. The absorption kinetics, mechanical strength, and adequate surface are important factors for maintaining cell viability, and scaffold permanent stability. Bone scaffolds provide a surface area for bone cells to aggregate and proliferate by providing mechanical stability and protection to the area and cell attachment sites. An average standard pore size of $100 \mu \mathrm{m}$ in a bone scaffold in an interconnected arrangement with osteoprogenitor cell colonization allows new bone tissue to be formed. In some cases, $\geq 300 \mu \mathrm{m}$ pore size has been used. Large pore size can mature bone formation, which leads to angiogenesis and invasion of nerve fibers (Shapiro and Cohen, 1997; Zmora et al., 2002; PoloCorrales et al., 2014). However, greater increase in pore size may reduce cell-adhering properties due to reduced volume-tosurface area ratio (Sarker et al., 2014).

Natural bioceramics have excellent compressive strength, high resistance, and low frictional properties (Green et al., 2003; Baino and Vitale-Brovarone, 2014, 2015; Baino and Verné, 2017; Tagliabue et al., 2017). They can be found in marine sponges and corals (Ben-Nissan, 2003). These biomaterials have shown osteoprogenitor cell attachment, growth, and differentiation in vitro (Baino and Ferraris, 2017). Coral scaffolds and coral derivatives have been studied in various clinical treatments including spinal fusion, maxillofacial surgery, and dental surgery (Martina et al., 2005; Coughlin et al., 2006; Oliveira et al., 2007; Chen et al., 2008). Marine sponges are also naturally derived ceramics that have an interconnected porous architecture. An organic marine sponge was mimicked to vertebral collagen (Granito et al., 2017). These sponges possess properties that help in promoting cell growth, bone mineralization, and bone formation (Clarke et al., 2015; Nandi et al., 2015).

Natural polymers in bone TE include proteins and polysaccharides. A unique group of natural proteins such as collagen, gelatin, silk fibroin, and fibrin has been studied in bone TE. Different forms of film, sponge, and fiber are generated using 3D scaffolds made partially, or totally of these proteins (Sayin et al., 2014). Collagen and denatured form of collagen, gelatin, possess excellent properties including low antigenicity, low inflammatory, and cytotoxic response and excellent cell compatibility (Ferreira et al., 2012). The limitations on high degradation rate, which results in loss of various mechanical properties, was overcome by crosslinking them with chemicals (Green et al., 2003; Ferreira et al., 2012; Kane and Roeder, 2012). Natural fibrous proteins, mainly silkworm fibroin, are highly used in the development of bioengineered constructs due to good elasticity, strength, and compatible to mammalian cells (Melke et al., 2016). The Silkworm fibroin is used in musculoskeletal TE as mineralized and nanofibrous scaffolds (Bhattacharjee et al., 2017). Fibrin has been used for its excellent biocompatibility, controllable biodegradability, and good ability to be a drug carrier (Park et al., 2009; Galler et al., 2011). Polysaccharides have unique properties such as lack of toxicity, biodegradability, stability to $\mathrm{pH}$ variations, and range of chemical structures (Noori et al., 2017).
Chitosan can support the proliferation of osteoblast cells, mineralized bone matrix, and neovascularization (Costa-Pinto et al., 2011). Chitosan-pectin hydrogel conjugation resulted in regeneration of alveolar bone (Iviglia et al., 2016). Alginate is a natural polysaccharide obtained from brown algae and seaweed. This is highly effective due to its biocompatibility, low toxicity, and relatively low cost. It has been very effective in $3 \mathrm{D}$ cell matrices and now has been used in bone scaffold research (Shapiro and Cohen, 1997; Zmora et al., 2002; Polo-Corrales et al., 2014). It forms a hydrogel when certain divalent atoms are chemically crosslinked through ionic interaction between the cationic and the carboxyl functional groups (Shapiro and Cohen, 1997; Draget et al., 2005; Turco et al., 2009; PoloCorrales et al., 2014). Similarly, bioglass has a huge impact in support bone healing and coat orthopedic implants and improves the interface between prostheses and living tissues (Xie et al., 2010). These bioactive silicate glass are considered under class A bioactive materials. Recently, sodium alginate (Figure 2B) is used in fabrication with glass particles in conjugation with strontium and zinc to synthesize porous, biocompatible novel composite scaffold (Hatton et al., 2019).

Synthetic biomaterials including bioceramics and synthetic polymers are polyesters and poly-andrihydes. Calcium phosphates and bioactive glasses are the most common biocompatible materials due to their osteoconductive and osteoinductive properties (Habraken et al., 2016). Studies have also utilized bioactive glasses in bone/tooth repair and regeneration (Kargozar et al., 2016). Polyesters (PGA) are mainly used in sutures and biomedical implants because of their high crystalline nature, high melting point, tensile modulus, and controlled solubility. Limitation of PGA was overcome by adding $\beta$-TCP for controlled polymer degradation and regeneration of hard tissues (Cao and Kuboyama, 2010). Poly(lactic acid) (PLA) can be modified with other biomaterials using modifiers, blending, copolymerization, and physical treatments. PLA with bioactive glasses improved biological properties such as osteoblast cell growth or differentiation (Haimi et al., 2008). Poly(lactic-co-glycolic acid) (PLGA) is an excellent source that can be modified into different forms such as scaffolds, fibers, hydrogels, or injectable microspheres. PLGA with inorganic materials is used to improve bioactivity and osteoconductivity (Jose et al., 2009). Poly( $\varepsilon$-caprolactone) (PCL), a hydrophobic, semicrystalline polymer with a low melting point, has caught the attention of biomedical researchers due to its ability to improve osteoblast activity (Ciapetti et al., 2003). Poly(ethylene glycol) (PEG), also known as polyethylene oxide (PEO) or polyoxyethylene (POE), is a non-toxic and water-soluble polymer. Because of good biocompatibility, biodegradation, and low immunogenicity, this polymer is identified as a good candidate for medical applications, as it is tailored in a way that many mechanical properties can be improved.

\section{PANCREAS TE}

Reprogramming of human liver cells into insulin-secreting pancreatic $\beta$ cells has been successfully validated to maintain 
normal blood glucose level. Previous studies have shown an increase in insulin secretion on PEG hydrogel matrix encapsulation with pancreatic islets in rat bone marrow-derived MSCs. This construct was designed for the treatment of type 1 diabetes mellitus (TIDM), and when amount of glucose was elevated, results were shown by an increase in insulin level (Bal et al., 2017). Insulin-secreting pancreatic islet cells have poor proliferation capacity, but the use of these cells with proper scaffolds has seen an improvement in blood glucose level (GefenHalevi et al., 2010). Activation of transcription factors, which play a role in $\beta$ cell regeneration, can be utilized to generate insulin-secreting pancreatic islet cells. Other transcription factors such as pancreatic duct alpha cells are also considered under new strategy development (Mellado-Gil et al., 2012; Ben-Othman et al., 2013; Das et al., 2014). To promote 3D growth of pancreatic tissue, scaffold matrix is essential. PLGA scaffolds have been used in diabetic mice to reverse hyperglycemia. Moreover, these PLGS hybrid meshes coated with various natural biopolymers in 3D culture of RIN5 cells, which resulted in stimulating insulin secretion, supported extra adhesion, proliferation, and differentiation of RIN5 cells. Encapsulation of silybin (Sb) molecules by PLGA along with solvent diffusion of acetone in water was engineered to diffuse interface turbulence. However, PLGA is sensitive to hydrolysis while passing through the gastrointestinal tract. Thus, chitosan due to its cationic property was used to enhance mucoadhesive permeability along with PLGA itself. This conjugation promoted serum insulin-reduced blood sugar in diabetic mice, which indicated regeneration of $\beta$ cell regeneration in the pancreas. Further, upon increasing $\mathrm{Sb}$ content in conjugation, there is an increase in serum insulin (as an indicator of hyperglycemic damage restoration) and reduction in glycated hemoglobin levels and restoration of the liver glycogen (Figure 2C, Hinderer et al., 2016).

Many nanofibrils have also been under investigation, and use of nanofibril-shaped biomaterials has increasing evidence in TE. Collagen, a natural ECM, has emerged as a novel fundamental component of the natural ECM. Collagen is biodegradable and biocompatible, which are essential properties in drug, gene, and protein delivery systems. Emulsification solvent evaporation and emulsification solvent diffusion are the two methods used for fabrication of collagen in thin films or nanosized particles (Hinderer et al., 2016). Cell-based therapy using MSCs for the treatment of diabetes is also a novel material in TE. In conjugation with ECM, differentiation and stimulation of insulin-secreting cells are achieved (Ma et al., 2016). Further, to generate pancreatic islet-like clusters from MSCs, a culture medium developed by fabricating nanosized collagen with high-voltage electrostatic field system was used. Nicotinamide (NCT) and exendin4 (Ex4) promoted differentiation of MSCs into insulin mRNA-expressed and insulin-producing cells. This also showed pancreatic islet cell regeneration and regulation of blood glucose, which further reverses T2DM in rats, by ingestion of the differentiated cells derived from incubation of MSCs with collagen 1 nanofibrils/NCT/Ex4 (Niemeyer et al., 2010).

Non-surgical procedures also have a great potential in the clinical setting by providing biological treatments using interface constructs compatible to the host environment or themselves. In a recent study, a total of 33 sheep underwent anterior cruciate ligament (ACL) resection. The interface was constructed at the femoral and tibial bone tunnels using silkbased scaffold. The novel silk fiber-based scaffold for ACL regeneration demonstrated integration into the bone tunnels via the formation of a fibrous interzone. These interzone obtained similar structure as in surgical procedures, allografts, and autografts (Zheng et al., 2009; Teuschl et al., 2019).

\section{STEM CELL-BASED TE}

New therapeutic approaches utilize multipotential stem cells which may benefit from cellular engineering methods to increase cell survival, immunomodulatory signaling pathways, reducing inflammation and enhancing tissue repair. Stem cellbased therapies provide tremendous promise for repairing musculoskeletal conditions (Peng et al., 2011; Ren et al., 2012; Liu et al., 2014; Kuroda et al., 2015; Kharaziha et al., 2016). Recently, various studies have been designed by combining recent advances in gene editing, synthetic biology, and TE. These designer cells have required cell surface and receptors that will provide a strong scaffold for tissue repair and regeneration. In orthopedics, embryonic stem cells, induced pluripotent stem cells, and adult stem cells, also termed as MSCs, are the most explored in musculoskeletal conditions (Liu et al., 2008). The functions of MSCs include direct differentiation to become a cell, assigning roles to other cells, and creation of regenerative pathways via production of various growth factors. MSCs have been promising and a living therapeutic solution for functional and restoration of musculoskeletal problems. Different kinds of stem cells have been utilized in recent research studies as discussed in Table $\mathbf{1 .}$

\section{CHALLENGES, FUTURE PERSPECTIVE, AND CONCLUSIONS}

The accuracy and efficiency of bioengineered constructs are very challenging, as they require a deep understanding with regard to mechanisms of regeneration. New treatment approaches are required, as designing new nanostructures and constructs can provide more precise, target-specific scaffolds with varying functionalities. For example, only drugs and/or heart transplantation solutions are available for cardiac diseases. In summary, bio-mimicked constructs possess advanced architectures and surface topography like native tissues and organs to recover intrinsic properties of damaged tissues and organs. It is possible to change cell behavior using nanoenabling platforms, which can be modified using their unique properties. Various methods are used such as nanolithography, electrospinning, nano-enabled patterning, and electrochemical to enhance protein adsorption, cellular attachment, proliferation, differentiation without affecting immune cascade, and different signaling pathways. Thus, designing constructs to understand physiochemical interactions with living tissues can significantly advance the field of TE and regenerative medicine. This article introduces recent work using new bio-mimicked biomaterial 
TABLE 1 | Various types of stem cells are utilized in treating defects and increasing tissue repair and regeneration for different cell types.

\begin{tabular}{|c|c|c|c|c|c|}
\hline Engineering & Cell type & Source type & Type of defect/diseases/injury & Implants & References \\
\hline Gene editing & $\begin{array}{l}\text { cyclooxygenase } 2 \text { upstream } \\
\text { of the IL-4 gene, B cells } \\
\text { (NF-kB), IL-4 as a regulator } \\
\text { of macrophages }\end{array}$ & $\begin{array}{l}\text { Promoter gene, multiple } \\
\text { consensus elements for the } \\
\text { nuclear factor kappa-light-chain }\end{array}$ & $\begin{array}{l}\text { Inflammation, homing, and retention, } \\
\text { amplification and increased } \\
\text { expression of anticytokine drugs such } \\
\text { IL-1Ra in response to IL-1, improving } \\
\text { responses to inflammatory cytokines }\end{array}$ & $\begin{array}{l}\text { self-limiting promoter construct, synthetic } \\
\text { gene promoter system, synthesis of IL-4 }\end{array}$ & $\begin{array}{l}\text { Lin et al., 2017; Guilak et al., } \\
\text { 2019; Pferdehirt et al., } 2019\end{array}$ \\
\hline $\begin{array}{l}\text { Bone Marrow } \\
\text { Engineering }\end{array}$ & MSCs & Bone Marrow & $\begin{array}{l}\text { Mandibular, Metatarsal, Femoral } \\
\text { head, Femurs, Tibial, Tibial diaphyseal } \\
\text { defect, Craniofacial, Inferior orbital rim } \\
\text { bone, Tibial, Jaw bone loss }\end{array}$ & $\begin{array}{l}\text { MSCs + PRP injection, MSC-seeded BCP } \\
\text { scaffold implantation, MSC-seeded } \beta \text {-TCP } \\
\text { scaffold implantation, Preosteogenically } \\
\text { differentiated MSC, transplantation, hMSC } \\
\text { transplantation }\end{array}$ & $\begin{array}{l}\text { Linero and Chaparro, } 2014 \\
\text { Lucarelli et al., } 2005 \\
\text { Zhou et al., } 2011 \\
\text { Li et al., } 2007 \\
\text { Sijbesma et al., } 1997 \\
\text { Hou et al., } 1491 \\
\text { Pferdehirt et al., } 2019 \\
\text { Field et al., } 2011 \\
\text { Liao et al., } 2011\end{array}$ \\
\hline $\begin{array}{l}\text { Skeletal Muscle } \\
\text { Engineering }\end{array}$ & MDSCs & Skeletal Muscle & Skull, Calvarial & $\begin{array}{l}\text { BMP-2, VEGF, sFlt1 expressing MDSC } \\
\text { transplantation, BMP-4 expressing MDSC } \\
\text { transplantation }\end{array}$ & Usas et al., 2009 \\
\hline Adipose TE & ASCs, MSCs & Adipose Tissue & $\begin{array}{l}\text { Parietal bones, Ulna, OA-like } \\
\text { damage, Jaw bone }\end{array}$ & $\begin{array}{l}\text { MSC-seeded coral scaffold implantation, } \\
\text { US2/US3 gene-transfected ASC } \\
\text { transplantation, hASC injection, hMSC } \\
\text { transplantation }\end{array}$ & $\begin{array}{l}\text { Linero and Chaparro, } 2014 \\
\text { Cui et al., } 2007 \\
\text { Yamada et al., } 2004 \\
\text { Wang et al., } 2010\end{array}$ \\
\hline Fat TE & ASCs & Fat Tissue & Ulna & BMP-2-expressing ASC transplantation & $\begin{array}{l}\text { Kuroda et al., 2015; } \\
\text { Muylaert et al., } 2016\end{array}$ \\
\hline $\begin{array}{l}\text { Umbilical Cord } \\
\text { Engineering }\end{array}$ & MSCs & Umbilical cord blood & Radial & MSC injection & Sijbesma et al., 1997 \\
\hline Teeth Engineering & DPSCs & Teeth & Mandibular & DPSC transplantation & Bueno et al., 2009 \\
\hline Orbicular Oris Muscle & MDSCs & Orbicular oris muscle & Cranial defect & hMDSC transplantation & Gao et al., 2014 \\
\hline Cardiac TE & Hydrated ECM & Cardiovascular tissue & $\begin{array}{l}\text { complete replacement of lost or } \\
\text { damaged tissues, }\end{array}$ & $\begin{array}{l}\text { hydrogels bonding motifs } \\
\text { (Stimuli-Responsive Cyclodextrin } \\
\text { Derivatives, Cyclodextrin Derivatives, } \\
\text { Benzene-1,3,5-Tricarboxamide, } \\
\text { Ureidopyrimidinone) }\end{array}$ & $\begin{array}{l}\text { Hou et al., 1491; } \\
\text { Rachakonda et al., 2008; } \\
\text { Highley et al., 2015; } \\
\text { Khodaverdi et al., 2016; } \\
\text { Muylaert et al., } 2016\end{array}$ \\
\hline Skin TE & MSC & Bone marrow & $\begin{array}{l}\text { Repairing burn wounds, healing, } \\
\text { keratinization, more vascularization }\end{array}$ & Collagen-GAG scaffolds, & Liu et al., 2008 \\
\hline Nerve TE & $\begin{array}{l}\text { Embryonic Stem Cells, } \\
\text { MSCs, and neural stem cells }\end{array}$ & Skin fibroblasts & $\mathrm{PD}, \mathrm{HD}, \mathrm{ALS}$, and $\mathrm{AD}$ & $\begin{array}{l}\text { Induced pluripotent stem cells, genetic } \\
\text { manipulation, and gene transfer }\end{array}$ & Su et al., 2013 \\
\hline
\end{tabular}

IL-4, interleukin-4;BMP-2, bone morphogenic protein-2; NF-kB, nuclear factor KB; PRP, platelet-rich plasma; BCP, biphasic calcium phosphate; VEGF, vascular endothelial growth factor; hMSC, human mesenchymal stem cell; MDSC, myeloid-derived suppressor cell; ASC, adipose-derived stromal cells; OA, osteoarthritis; hASC, adipose-derived stromal cell; DPSC, dental pulp stem cell; GAG, glycosaminoglycan; PD, Parkinson's disease; HD, Huntington's disease; ALS, amyotrophic lateral sclerosis; $A D$, Alzheimer's disease. 
constructs designed to overcome disease and defects from tissue injury. By mimicking complex environment using nanoparticles to nanocomposite materials to nanopatterned materials, the cardiac TE has the potential to improve cardiac health and medicine. Successful application would help reduce significant dependence on heart donors in the treatment of cardiac failure. As shown in Figure 2, nanoscale patterning and texturing are another approach that hold great promise in the field of cardiac TE.

Interface TE has the potential to regenerate anatomic interface between different tissue types. The main challenges in building interfaces are how boundaries are defined with the tissue constructs, re-established postinjury, and maintaining these mimicked constructs within the body. This will bring greater understanding of the structure-function relationship of biomolecules and receptors at the site of insertion and the mechanism behind interface generation. Engineering multiple tissue types along with dense interconnected interactions will play important an role in unfolding complications in interface design. New constructs are critical to understand the theory behind the differentiation, proliferation, and migrations of cells. Stem cells provide tremendous opportunities for the development of novel therapies for a range of musculoskeletal disorders. With the advent of a new generation of stem cell therapies, new methods for TE will emerge that can provide functional tissue replacements.

\section{REFERENCES}

Amezcua, R., Shirolkar, A., Fraze, C., and Stout, D. (2016). Nanomaterials for cardiac myocyte tissue engineering. Nano 6:133. doi: 10.3390/nano6070133

Baino, F., and Ferraris, M. (2017). Learning from nature: using bioinspired approaches and natural materials to make porous bioceramics. Int. J. Appl. Ceram. Tec. 14, 507-520. doi: 10.1111/ijac.12677

Baino, F., and Verné, E. (2017). Production and characterization of glassceramic materials for potential use in dental applications: thermal and mechanical properties, microstructure, and in vitro bioactivity. Appl. Sci. 7:1330. doi: 10.3390/app7121330

Baino, F., and Vitale-Brovarone, C. (2014). Mechanical properties and reliability of glass-ceramic foam scaffolds for bone repair. Mater. Lett. 118, 27-30. doi: 10.1016/j.matlet.2013.12.037

Baino, F., and Vitale-Brovarone, C. (2015). Wollastonite-containing bioceramic coatings on alumina substrates: design considerations and mechanical modelling. Ceram. Int. 41, 11464-11470. doi: 10.1016/j.ceramint.2015.05.111

Bal, T., Nazli, C., Okcu, A., Duruksu, G., Karaoz, E., and Kizilel, S. (2017). Mesenchymal stem cells and ligand incorporation in biomimetic poly(ethylene glycol) hydrogels significantly improve insulin secretion from pancreatic islets. J. Tissue Eng. Regen. Med. 11, 694-703. doi: 10.1002/term.1965

Baroli, B. (2007). Hydrogels for tissue engineering and delivery of tissue-inducing substances. J. Pharm. Sci. 96, 2197-2223. doi: 10.1002/jps.20873

Ben-Nissan, B. (2003). Natural bioceramics: from coral to bone and beyond. Curr. Opin. Solid State Mater. Sci. 7, 283-288. doi: 10.1016/j.cossms.2003.10.001

Ben-Othman, N., Courtney, M., Vieira, A., Pfeifer, A., Druelle, N., Gjernes, E., et al. (2013). From pancreatic islet formation to beta-cell regeneration. Diabetes Res. Clin. Pract. 101, 1-9. doi: 10.1016/j.diabres.2013.01.013

Bhattacharjee, P., Kundu, B., Naskar, D., Kim, H.-W., Maiti, T. K., Bhattacharya, D., et al. (2017). Silk scaffolds in bone tissue engineering: an overview. Acta Biomater. 63, 1-17. doi: 10.1016/j.actbio.2017.09.027

Bueno, D. F., Kerkis, I., Costa, A. M., Martins, M. T., Kobayashi, G. S., Zucconi, E., et al. (2009). New source of muscle-derived stem cells with potential for alveolar
The most successful approach was the design and synthesis of hybrid biomaterials until 3D printing came into the market. Important evaluation of 3D-printed tissues and organ engineering, the most innovative approach, improved and was accepted over the conventional culture systems but had no better results than the conventional approaches. Hence, more work needs to be done in this aspect to utilize its benefit. 3D bioprinting can advance current research and support novel therapeutics, which has excellent potential in curing cardiovascular pathologies as well. These methods and techniques therefore facilitate better protein adsorption, cellular attachment, proliferation, cellular attachment, and differentiation. Moreover, understanding surface interaction, mechanism, and their effect on bonding with living tissues can help in the advancement of tissue regeneration, and regenerative medicine.

\section{AUTHOR CONTRIBUTIONS}

All authors listed have made a substantial, direct and intellectual contribution to the work, and approved it for publication.

\section{ACKNOWLEDGMENTS}

All the authors acknowledge their respective departments and universities.

bone reconstruction in cleft lip and/or palate patients. Tissue Eng. 15:427-35. doi: 10.1089/ten.tea.2007.0417

Cao, H., and Kuboyama, N. (2010). A biodegradable porous composite scaffold of PGA/ $\beta$-TCP for bone tissue engineering. Bone 46, 386-339. doi: 10.1016/j.bone.2009.09.031

Cerbai, E., Pino, R., Sartiani, L., and Mugelli, A. (1999). Influence of postnataldevelopment on $\mathrm{I}(\mathrm{f})$ occurrence and properties in neonatal rat ventricular myocytes. Cardiovasc. Res. 42, 416-423. doi: 10.1016/S0008-6363(99) 00037-1

Chen, P.-Y., Lin, A. Y.-M., McKittrick, J., and Meyers, M. A. (2008). Structure and mechanical properties of crab exoskeletons. Acta Biomater. 4, 587-596. doi: 10.1016/j.actbio.2007.12.010

Chiarugi, P., and Giannoni, E. (2008). Anoikis: a necessary death program for anchorage-dependent cell. Biochem. Pharmacol. 76, 1352-1364. doi: 10.1016/j.bcp.2008.07.023

Christman, K. L., Fok, H. H., Sievers, R. E., Fang, Q., and Lee, R. J. (2004). Fibrin glue alone and skeletal myoblasts in a fibrin scaffold preserve cardiac function after myocardial infarction. Tissue Eng. 10, 403-409. doi: $10.1089 / 107632704323061762$

Chung, H. J., and Park, T. G. (2007). Surface engineered and drug-releasing prefabricated scaffolds for tissue engineering. Adv. Drug Deliv. Rev. 59, 249-262. doi: 10.1016/j.addr.2007.03.015

Ciapetti, G., Ambrosio, L., Savarino, L., Granchi, D., Cenni, E., Baldini, N., et al. (2003). Osteoblast growth and function in porous poly $\varepsilon$-caprolactone matrices for bone repair: a preliminary study. Biomaterials 24, 3815-3824. doi: 10.1016/S0142-9612(03)00263-1

Clarke, S. A., Choi, S. Y., McKechnie, M., Burke, G., Dunne, N., Walker, G., et al. (2015). Osteogenic cell response to 3-D hydroxyapatite scaffolds developed via replication of natural marine sponges. J. Mater. Sci. Mater. Med. 27:22. doi: 10.1007/s10856-015-5630-0

Costa-Pinto, A. R., Reis, R. L., and Neves, N. M. (2011). Scaffolds based bone tissue engineering: the role of chitosan. Tissue Eng. Part B Rev. 17, 331-347. doi: 10.1089/ten.teb.2010.0704 
Coughlin, M. J., Grimes, J. S., and Kennedy, M. P. (2006). Coralline hydroxyapatite bone graft substitute in hindfoot surgery. Foot Ankle Int. 27, 19-22. doi: 10.1177/107110070602700104

Cui, L., Liu, B., Liu, G., Zhang, W., Cen, L., Sun, J., et al. (2007). Repair of cranial bone defects with adipose derived stem cells and coral scaffold in a canine model. Biomaterials 28, 5477-5486. doi: 10.1016/j.biomaterials.2007.08.042

Das, S., Roy, P., Pal, R., Auddy, R. G., Chakraborti, A. S., and Mukherjee, A. (2014). Engineered silybin nanoparticles educe efficient control in experimental diabetes. PLoS ONE 9:e101818. doi: 10.1371/journal.pone.0101818

Dattola, E., Mollacea, V., and Lamannaa, E. (2019). Development of 3D PVA scaffolds for cardiac tissue engineering and cell screening applications. RSC Adv. 9, 4246-4257. doi: 10.1039/C8RA08187E

Domb, A., and Mikos, A. G. (2007). Matrices and scaffolds for drug delivery in tissue engineering. Adv. Drug Deliv. Rev. 59, 185-186. doi: 10.1016/j.addr.2007.05.001

Draget, K., Smidsrød, O., and Skjåk-Bræk, G. (2005). Alginates from algae. Biol. Chem. Biotechnol. Appl. 6, 1-30. doi: 10.1002/3527600035.bpol6008

Engelmayr, G. C. Jr., Cheng, M., Bettinger, C. J., Borenstein, J. T., Langer, R., and Freed, L. E. (2008). Accordion-like honeycombs for tissue engineering of cardiac anisotropy. Nat. Mater. 7, 1003-1010. doi: 10.1038/nmat2316

Eschenhagen, T., and Zimmermann, W. H. (2005). Engineering myocardial tissue. Circ. Res. 97, 1220-1231. doi: 10.1161/01.RES.0000196562.73231.7d

Ferreira, A. M., Gentile, P., Chiono, V., and Ciardelli, G. (2012). Collagen for bone tissue regeneration. Acta Biomater. 8, 3191-3200. doi: 10.1016/j.actbio.2012.06.014

Field, J. R., McGee, M., Stanley, R., Ruthenbeck, G., Papadimitrakis, T., Zannettino, A., et al. (2011). The efficacy of allogeneic mesenchymal precursor cells for the repair of an ovine tibial segmental defect. Vet. Comp. Orthop. Traumatol. 24, 113-121. doi: 10.3415/VCOT-10-03-0046e

Fleischer, S., Shevach, M., Feiner, R., and Dvir, T. (2014). Coiled fiber scaffolds embedded with gold nanoparticles improve the performance of engineered cardiac tissues. Nano 6, 9410-9414. doi: 10.1039/C4NR00300D

Fujimoto, K. L., Ma, Z., Nelson, D. M., Hashizume, R., Guan, J., Tobita, K., et al. (2009). Synthesis, characterization and therapeutic efficacy of a biodegradable, thermoresponsive hydrogel designed for application in chronic infarcted myocardium. Biomaterials 30, 4357-4368. doi: 10.1016/j.biomaterials.2009.04.055

Furuta, A., Miyoshi, S., Itabashi, Y., Shimizu, T., Kira, S., Hayakawa, K., et al. (2006). Pulsatile cardiac tissue grafts using a novel three-dimensional cell sheet manipulation technique functionally integrates with the host heart, in vivo. Circ. Res. 98, 705-712. doi: 10.1161/01.RES.0000209515. 59115.70

Galler, K. M., Cavender, A. C., Koeklue, U., Suggs, L. J., Schmalz, G., and D'Souza, R. N. (2011). Bioengineering of dental stem cells in a PEGylated fibrin gel. Regen. Med. 6, 191-200. doi: 10.2217/rme.11.3

Gao, X., Usas, A., Proto, J. D., Lu, A., Cummins, J. H., Proctor, A., et al. (2014). Role of donor and host cells in muscle-derived stem cell-mediated bone repair: differentiation vs paracrine effects. FASEB J. 28, 3792-3809. doi: 10.1096/fj.13-247965

Gefen-Halevi, S., Rachmut, I. H., Molakandov, K., Berneman, D., Mor, E., Meivar-Levy, I., et al. (2010). NKX6.1 promotes PDX-1-induced liver to pancreatic beta-cells reprogramming. Cell. Reprogram. 12, 655-664. doi: $10.1089 /$ cell.2010.0030

Granito, R. N., Custódio, M. R., and Rennó, A. C. M. (2017). Natural marine sponges for bone tissue engineering: the state of art and future perspectives. J. Biomed. Mater. Res. Part B Appl. Biomater. 105, 1717-1727. doi: $10.1002 /$ jbm.b.33706

Green, D., Howard, D., Yang, X., Kelly, M., and Oreffo, R. (2003). Natural marine sponge fiber skeleton: a biomimetic scaffold for human osteoprogenitor cell attachment, growth, and differentiation. Tissue Eng. 9, 1159-1166. doi: 10.1089/10763270360728062

Guilak, F., Pferdehirt, L., Ross, A. K., Choi, Y. R., Collins, K. H., Nims, R. J., et al. (2019). Designer stem cells: genome engineering and the next generation of cell-based therapies. J. Orthop. Res. 37, 1287-1293. doi: 10.1002/jor. 24304

Habraken, W., Habibovic, P., Epple, M., and Bohner, M. (2016). Calcium phosphates in biomedical applications: materials for the future? Mater. Today 19, 69-87. doi: 10.1016/j.mattod.2015.10.008
Haimi, S., Suuriniemi, N., Haaparanta, A.-M., Ellä, V., Lindroos, B., Huhtala, H., et al. (2008). Growth and osteogenic differentiation of adipose stem cells on PLA/bioactive glass and PLA/ $\beta$-TCP scaffolds. Tissue Eng. Part A 15, 1473-1480. doi: 10.1089/ten.tea.2008.0241

Han, J., Kim, B., Shin, J. Y., Ryu, S., Noh, M., Woo, J., et al. (2015). Iron oxide nanoparticle-mediated development of cellular gap junction crosstalk to improve mesenchymal stem cells' therapeutic efficacy for myocardial infarction. ACS Nano 9, 2805-2819. doi: 10.1021/nn506732n

Hatton, J., Davis, G. R., and Hill, R. G. (2019). Fabrication of porous bone scaffolds using alginate and bioactive glass. J. Funct. Biomater. 10:15. doi: 10.3390/jfb10010015

Highley, C. B., Rodell, C. B., and Burdick, J. A. (2015). Direct 3D printing of shearthinning hydrogels into self-healing hydrogels. Adv. Mater. 27, 5075-5079. doi: 10.1002/adma.201501234

Hinderer, S., Layland, S. L., and Schenke-Layland, K. (2016). ECM and ECM-like materials-biomaterials for applications in regenerative medicine and cancer therapy. Adv. Drug Deliv. Rev. 97:260-269. doi: 10.1016/j.addr.2015.11.019

Hou, S., Wang, X., Park, S., Jin, X., and Ma, P. X. (1491). Rapid self-integrating, injectable hydrogel for tissue complex regeneration. Adv. Healthc. Mater. 4, 1491-1495. doi: 10.1002/adhm.201500093

Huynh, T. V., Chen, F., Wetzel, G. T., Friedman, W. F., and Klitzner, T. S. (1992). Developmental changes in membrane Ca2 + and $\mathrm{K}+$ currents in fetal, neonatal, and adult rabbit ventricular myocytes. Circ. Res. 70, 508-515. doi: 10.1161/01.RES.70.3.508

Iviglia, G., Cassinelli, C., Torre, E., Baino, F., Morra, M., and Vitale-Brovarone, C. (2016). Novel bioceramic-reinforced hydrogel for alveolar bone regeneration. Acta Biomater. 44, 97-109. doi: 10.1016/j.actbio.2016.08.012

Jose, M. V., Thomas, V., Johnson, K. T., Dean, D. R., and Nyairo, E. (2009). Aligned PLGA/HA nanofibrous nanocomposite scaffolds for bone tissue engineering. Acta Biomater. 5, 305-315. doi: 10.1016/j.actbio.2008.07.019

Kane, R. J., and Roeder, R. K. (2012). Effects of hydroxyapatite reinforcement on the architecture and mechanical properties of freeze-dried collagen scaffolds. J. Mech. Behav. Biomed. Mater. 7, 41-49. doi: 10.1016/j.jmbbm.2011.09.010

Kang, M. S., Kim, J. H., Singh, R. K., Jang, J. H., and Kim, H. W. (2015). Therapeutic-designed electrospun bone scaffolds: mesoporous bioactive nanocarriers in hollow fiber composites to sequentially deliver dual growth factors. Acta Biomater. 16, 103-116. doi: 10.1016/j.actbio.2014.12.028

Kargozar, S., Lotfibakhshaiesh, N., Ai, J., Samadikuchaksaraie, A., Hill, R. G., Shah, P. A., et al. (2016). physico-chemical and biological characterization of strontium and cobalt substituted bioactive glasses for bone tissue engineering. J. Non Cryst. Solids 449, 133-140. doi: 10.1016/j.jnoncrysol.2016.07.025

Khademhosseini, A., Eng, G., Yeh, J., Kucharczyk, P. A., Langer, R., VunjakNovakovic, G., et al. (2007). Microfluidic patterning for fabrication of contractile cardiac organoids. Biomed. Microdevices 9, 149-157. doi: 10.1007/s10544-006-9013-7

Kharaziha, M., Memic, A., Akbari, M., Brafman, D. A., and Nikkhah, M. (2016). Nano-enabled approaches for stem cell-based cardiac tissue engineering. Adv. Healthc. Mater. 5, 1533-1553. doi: 10.1002/adhm.201600088

Khodaverdi, E., Gharechahi, M., Alibolandi, M., Tekie, F. S. M., Khashyarmanesh, B. Z., and Hadizadeh, F. (2016). Self-assembled supramolecular hydrogel based on PCL-PEG-PCL triblock copolymer and $\gamma$-cyclodextrin inclusion complex for sustained delivery of dexamethasone. Int. J. Pharm. Investig. 6, 78-85. doi: 10.4103/2230-973X.177809

Kojima, M., Sada, H., and Sperelakis, N. (1990). Developmental changes in beta-adrenergic and cholinergic interactions on calcium-dependent slow action potentials in rat ventricular muscles. Br. J. Pharmacol. 99, 327-333. doi: 10.1111/j.1476-5381.1990.tb14703.x

Kraehenbuehl, T. P., Zammaretti, P., Van der Vlies, A. J., Schoenmakers, R. G., Lutolf, M. P., Jaconi, M. E., et al. (2008). Three-dimensional extracellular matrix-directed cardioprogenitor differentiation: systematic modulation of a synthetic cell-responsive PEG-hydrogel. Biomaterials 29, 2757-2766. doi: 10.1016/j.biomaterials.2008.03.016

Kuroda, K., Kabata, T., Hayashi, K., Maeda, T., Kajino, Y., Iwai, S., et al. (2015). The paracrine effect of adipose-derived stem cells inhibits osteoarthritis progression. BMC Musculoskelet. Disord. 16:236. doi: 10.1186/s12891-015-0701-4

Kutschka, I., Chen, I. Y., Kofidis, T., Arai, T., von Degenfeld, G., Sheikh, A. Y., et al. (2006). Collagen matrices enhance survival of transplanted cardiomyoblasts 
and contribute to functional improvement of ischemic rat hearts. Circulation 114 (Suppl. 1), I167-I173. doi: 10.1161/CIRCULATIONAHA.105.001297

Li, H., Dai, K., Tang, T., Zhang, X., Yan, M., and Lou, J. (2007). Bone regeneration by implantation of adipose-derived stromal cells expressing BMP-2. Biochem. Biophys. Res. Commun. 356, 836-842. doi: 10.1016/j.bbrc.2007.02.165

Li, H., Fierens, K., Zhang, Z., Vanparijs, N., Schuijs, M. J., Van Steendam, K., et al. (2016). Spontaneous protein adsorption on graphene oxide nanosheets allowing efficient intracellular vaccine protein delivery. ACS Appl. Mater. Interfaces 8, 1147-1155. doi: 10.1021/acsami.5b08963

Liao, H. T., Chen, C. T., Chen, C. H., Chen, J. P., and Tsai, J. C. (2011). Combination of guided osteogenesis with autologous platelet-rich fibrin glue and mesenchymal stem cell for mandibular reconstruction. J. Trauma 70, 228-237. doi: 10.1097/TA.0b013e3181e12b56

Lin, T., Pajarinen, J., Nabeshima, A., Lu, L., Nathan, K., Yao, Z., et al. (2017). Establishment of NF-kappaB sensing and interleukin-4 secreting mesenchymal stromal cells as an "on-demand" drug delivery system to modulate inflammation. Cytotherapy 19, 1025-1034. doi: 10.1016/j.jcyt.2017.06.008

Linero, I., and Chaparro, O. (2014). Paracrine effect of mesenchymal stem cells derived from human adipose tissue in bone regeneration. PLoS ONE 9:e107001. doi: 10.1371/journal.pone.0107001

Liu, P., Deng, Z., Han, S., Liu, T., Wen, N., Lu, W., et al. (2008). Tissue-engineered skin containing mesenchymal stem cells improves burn wounds. Artif. Organs. 32, 925-931. doi: 10.1111/j.1525-1594.2008.00654.x

Liu, X., Liao, X., Luo, E., Chen, W., Bao, C., and Xu, H. H. (2014). Mesenchymal stem cells systemically injected into femoral marrow of dogs home to mandibular defects to enhance new bone formation. Tissue Eng. 20, 883-92. doi: $10.1089 /$ ten.tea.2012.0677

Lucarelli, E., Fini, M., Beccheroni, A., Giavaresi, G., Di Bella, C., Aldini, N. N., et al. (2005). Stromal stem cells and platelet-rich plasma improve bone allograft integration. Clin. Orthop. Relat. Res. 435, 62-68. doi: 10.1097/01.blo.0000165736.87628.12

Ma, C. T., Wu, Y. J., Huang, H. H., Kang, P. L., Hsiao, K. Y., Lo, D. Y., et al. (2016). In vitro and in vivo evaluation of the effect of nano-sized collagen molecules and nicotinamide on mesenchymal stem cell differentiation. J. Mater. Chem. B 4, 3892-3902. doi: 10.1039/С6TB00731G

Ma, Z., Mao, Z., and Gao, C. (2007). Surface modification and property analysis of biomedical polymers used for tissue engineering. Colloids Surf. B Biointerfaces 60, 137-157. doi: 10.1016/j.colsurfb.2007.06.019

Macchiarelli, G., Ohtani, O., Nottola, S. A., Stallone, T., Camboni, A., Prado, I. M., et al. (2002). A micro-anatomical model of the distribution of myocardial endomysial collagen. Histol. Histopathol. 17, 699-706. doi: $10.14670 / \mathrm{HH}-17.699$

Martina, M., Subramanyam, G., Weaver, J. C., Hutmacher, D. W., Morse, D. E., and Valiyaveettil, S. (2005). Developing macroporous bicontinuous materials as scaffolds for tissue engineering. Biomaterials 26, 5609-5616. doi: 10.1016/j.biomaterials.2005.02.011

Martinelli, V., Cellot, G., Toma, F. M., Long, C. S., Caldwell, J. H., Zentilin, L., et al. (2012). Carbon nanotubes promote growth and spontaneous electrical activity in cultured cardiac myocytes. Nano Lett. 12, 1831-1838. doi: 10.1021/nl204064s

Mehrali, M., Thakur, A., Pennisi, C. P., Talebian, S., Arpanaei, A., Nikkhah, M., et al. (2017). Nanoreinforced hydrogels for tissue engineering: biomaterials that are compatible with load-bearing and electroactive tissues. Adv. Mater. 29:1603612. doi: 10.1002/adma.201603612

Melke, J., Midha, S., Ghosh, S., Ito, K., and Hofmann, S. (2016). Silk fibroin as biomaterial for bone tissue engineering. Acta Biomater. 31, 1-16. doi: 10.1016/j.actbio.2015.09.005

Mellado-Gil, J. M., Cobo-Vuilleumier, N., and Gauthier, B. R. (2012). Islet beta-cell mass preservation and regeneration in diabetes mellitus: four factors with potential therapeutic interest. J. Transplant. 2012:230870. doi: $10.1155 / 2012 / 230870$

Muylaert, D. E., van Almen, G. C., Talacua, H., Fledderus, J. O., Kluin, J., Hendrikse, S. I., et al. (2016). Early in-situ cellularization of a supramolecular vascular graft is modified by synthetic stromal cell-derived factor-1 $\alpha$ derived peptides. Biomaterials 76, 187-195. doi: 10.1016/j.biomaterials.2015.10.052

Nandi, S. K., Kundu, B., Mahato, A., Thakur, N. L., Joardar, S. N., and Mandal, B. B. (2015). In vitro and in vivo evaluation of the marine sponge skeleton as a bone mimicking biomaterial. Integr Biol. 7, 250-262. doi: 10.1039/C4IB00289J
Navaei, A., Moore, N., Sullivan, R. T., Truong, D., Migrino, R. Q., Nikkhah, M., et al. (2017). Electrically conductive hydrogel-based micro-topographies for the development of organized cardiac tissues. RSC Adv. 7, 3302-3312. doi: 10.1039/C6RA26279A

Navaei, A., Saini, H., Christenson, W., Sullivan, R. T., Ros, R., and Nikkhah, M. (2016). Gold nanorod-incorporated gelatin-based conductive hydrogels for engineering cardiac tissue constructs. Acta Biomater. 41, 133-146. doi: 10.1016/j.actbio.2016.05.027

Niemeyer, P., Schonberger, T. S., Hahn, J., Kasten, P., Fellenberg, J., Suedkamp, N., et al. (2010). Xenogenic transplantation of human mesenchymal stem cells in a critical size defect of the sheep tibia for bone regeneration. Tissue Eng 16. Am. J. Sports Med. 17:20. doi: 10.1089/ten.tea.2009.0190

Noori, A., Ashrafi, S. J., Vaez-Ghaemi, R., Hatamian-Zaremi, A., and Webster, T. J. (2017). A review of fibrin and fibrin composites for bone tissue engineering. Int. J. Nanomed. 12, 4937-4961. doi: 10.2147/IJN.S124671

Oliveira, J. M., Grech, J. M., Leonor, I. B., Mano, J. F., and Reis, R. L. (2007). Calcium-phosphate derived from mineralized algae for bone tissue engineering applications. Mater. Lett. 61, 3495-3499. doi: 10.1016/j.matlet.2006.11.099

Park, J., Kim, B., Han, J., Oh, J., Park, S., Ryu, S., et al. (2015b). Graphene oxide flakes as a cellular adhesive: prevention of reactive oxygen species mediated death of implanted cells for cardiac repair. ACS Nano. 9, 4987-4999. doi: $10.1021 / \mathrm{nn} 507149 \mathrm{w}$

Park, J., Kim, Y. S., Ryu, S., Kang, W. S., Park, S., Han, J., et al. (2015a). Graphene potentiates the myocardial repair efficacy of mesenchymal stem cells by stimulating the expression of angiogenic growth factors and gap junction protein. Adv. Funct. Mater. 25, 2590-2600. doi: 10.1002/adfm.201500365

Park, K.-H., Kim, H., Moon, S., and Na, K. (2009). Bone morphogenic protein2 (BMP-2) loaded nanoparticles mixed with human mesenchymal stem cell in fibrin hydrogel for bone tissue engineering. J. Biosci. Bioeng. 108, 530-537. doi: 10.1016/j.jbiosc.2009.05.021

Patel, K. D., Singh, R. K., Mahapatra, C., Lee, E. J., and Kim, H. W. (2016). Nanohybrid electro-coatings toward therapeutic implants with controlled drug delivery potential for bone regeneration. J. Biomed. Nanotechnol. 12, 1876-1889. doi: 10.1166/jbn.2016.2301

Peng, J., Wen, C., Wang, A., Wang, Y., Xu, W., Zhao, B., et al. (2011). MicroCT-based bone ceramic scaffolding and its performance after seeding with mesenchymal stem cells for repair of load-bearing bone defect in canine femoral head. J. Biomed. Mater. Res. Part B Appl. Biomater. 96, 316-325. doi: $10.1002 /$ jbm.b. 31770

Pferdehirt, L., Ross, A. K., Brunger, J. M., and Guilak, F. (2019). A synthetic gene circuit for self-regulating delivery of biologic drugs in engineered tissues. Tissue Eng. 25:809-820. doi: 10.1089/ten.tea.2019.0027

Polo-Corrales, L., Latorre-Esteves, M., and Ramirez-Vick, J. E. (2014). Scaffold design for bone regeneration. J. Nanosci. Nanotechnol. 14, 15-56. doi: 10.1166/jnn.2014.9127

Pope, A. J., Sands, G. B., Smaill, B. H., and LeGrice, I. J. (2008). Three-dimensional transmural organization of perimysial collagen in the heart. Am. J. Physiol. Heart Circ. Physiol. 295:H1243-H1252. doi: 10.1152/ajpheart.00484.2008

Rachakonda, P. S., Rai, M. F., and Schmidt, M. F. (2008). Application of inflammation-responsive promoter for an in vitro arthritis model. Arthritis Rheum. 58, 2088-2097. doi: 10.1002/art.23598

Reis, L. A., Chiu, L. L. Y., Liang, Y., Hyunh, K., Momen, A., and Radisic, M. (2012). A peptide-modified chitosan-collagen hydrogel for cardiac cell culture and delivery. Acta Biomater. 8, 1022-1036. doi: 10.1016/j.actbio.2011. 11.030

Ren, M. L., Peng, W., Yang, Z. L., Sun, X. J., Zhang, S. C., Wang, Z. G., et al. (2012). Allogeneic adipose-derived stem cells with low immunogenicity constructing tissue-engineered bone for repairing bone defects in pigs. Cell Transplant. 21, 2711-2721. doi: 10.3727/096368912X654966

Richards, D. J., Tan, Y., Coyle, R., Li, Y., Xu, R., Yeung, N., et al. (2016). Nanowires and electrical stimulation synergistically improve functions of hiPSC cardiac spheroids. Nano Lett. 16, 4670-4678. doi: 10.1021/acs.nanolett. 6b02093

Rosamond, W., Flegal, K., Friday, G., Furie, K., Go, A., Greenlund, K., et al. (2007). Heart disease and stroke statistics-2007 update: a report from the American Heart Association Statistics Committee and Stroke Statistics Subcommittee. Circulation 115:e69-171. doi: 10.1161/CIRCULATIONAHA.106.179918 
Sarker, B., Singh, R., Silva, R., Roether, J. A., Kaschta, J., Detsch, R., et al. (2014). Evaluation of fibroblasts adhesion and proliferation on alginate-gelatin crosslinked hydrogel. PLoS ONE 9:e107952. doi: 10.1371/journal.pone.0107952

Sayin, E., Baran, E. T., and Hasirci, V. (2014). Protein-based materials in load-bearing tissue-engineering applications. Regen. Med. 9, 687-701. doi: $10.2217 /$ rme.14.52

Shapiro, L., and Cohen, S. (1997). Novel alginate sponges for cell culture and transplantation. Biomaterials 18, 583-590. doi: 10.1016/S0142-9612(96)00181-0

Shevach, M., Maoz, B. M., Feiner, R., Shapira, A., and Dvir, T. (2013). Nanoengineering gold particle composite fibers for cardiac tissue engineering. J. Mater. Chem. B 1, 5210-5217. doi: 10.1039/c3tb20584c

Shi, X., Chang, H., Chen, S., Lai, C., Khademhosseini, A., and Wu, H. (2012). Regulating cellular behavior on few-layer reduced graphene oxide films with well-controlled reduction states. Adv. Funct. Mater. 22, 751-759. doi: 10.1002/adfm.201102305

Shin, S. R., Farzad, R., Tamayol, A., Manoharan, V., Mostafalu, P., Zhang, Y. S., et al. (2016). A bioactive carbon nanotube-based ink for printing $2 \mathrm{D}$ and $3 \mathrm{D}$ flexible electronics. Adv. Mater. 28, 3280-3289. doi: 10.1002/adma.201506420

Sijbesma, R. P., Beijer, F. H., Brunsveld, L., Folmer, B. J. B., and Hirschberg, J. H. K. K. (1997). Reversible polymers formed from self-complementary monomers using quadruple hydrogen bonding. Science 278, 1601-1604.

Singh, R. K., Jin, G. Z., Mahapatra, C., Patel, K. D., Chrzanowski, W., and Kim, H. W. (2015). Mesoporous silica-layered biopolymer hybrid nanofibrous scaffold: a novel nanobiomatrix platform for therapeutics delivery and bone regeneration. ACS Appl. Mater. Interfaces 7, 8088-8098. doi: 10.1021/acsami.5b00692

Singh, R. K., Patel, K. D., Lee, J. H., Lee, E. J., Kim, J. H., Kim, T. H., et al. (2014). Potential of magnetic nanofiber scaffolds with mechanical and biological properties applicable for bone regeneration. PLOS ONE 9:e91584. doi: 10.1371/journal.pone.0091584

So, J. Y., Fang, Y. H., Lim, C. H., Kim, B. S., Son, H. S., Park, Y., et al. (2009). Regeneration of ischemic heart using hyaluronic acid-based injectable hydrogel. J. Biomed. Mater. Res. Part B Appl. Biomater. 91, 163-171. doi: $10.1002 /$ jbm.b.31386

Su, K., Lee, H. J., and Kim, Y. B. (2013). Neural stem cell-based treatment for neurodegenerative diseases. Neuropathology 33, 491-504. doi: 10.1111/neup. 12020

Tagliabue, S., Rossi, E., Baino, F., Vitale-Brovarone, C., Gastaldi, D., and Vena, P. (2017). Micro-CT based finite element models for elastic properties of glass-ceramic scaffolds. J. Mech. Behav. Biomed. Mater. 65, 248-255. doi: 10.1016/j.jmbbm.2016.08.020

Tan, Y., Richards, D., Coyle, R. C., Yao, J., Xu, R., Gou, W., et al. (2017). Cell number per spheroid and electrical conductivity of nanowires influence the function of silicon nanowired human cardiac spheroids. Acta Biomater. 51, 495-504. doi: 10.1016/j.actbio.2017.01.029

Teuschl, A. H., Tangl, S., and Heimel, P. (2019). Osteointegration of a novel silk fiber-based ACL scaffold by formation of a ligament-bone interface. Am. J. Sports Med. 47, 620-627. doi: 10.1177/0363546518818792

Turco, G., Marsich, E., Bellomo, F., Semeraro, S., Donati, I., Brun, F., et al. (2009). Alginate/hydroxyapatite biocomposite for bone ingrowth: a trabecular structure with high and isotropic connectivity. Biomacromolecules 10, 1575-1583. doi: 10.1021/bm900154b
Usas, A., Ho, A. M., Cooper, G. M., Olshanski, A., Peng, H., and Huard, J. (2009). Bone regeneration mediated by BMP4-expressing muscle-derived stem cells is affected by delivery system. Tissue Eng. 15, 285-293. doi: 10.1089/ten.tea.2008.0130

Wang, L., Fan, H., Zhang, Z. Y., Lou, A. J., Pei, G. X., Jiang, S., et al. (2010). Osteogenesis and angiogenesis of tissue-engineered bone constructed by prevascularized beta-tricalcium phosphate scaffold and mesenchymal stem cells. Biomaterials 31, 9452-9461. doi: 10.1016/j.biomaterials.2010.08.036

WHO Scientific Group (2003). The burden of musculoskeletal conditions at the start of the new millennium. World Health Organ. Tech. Rep. Ser. 919:i-x, 1-218.

Xie, X. H., Yu, X. W., Zeng, S. X., Du, R. L., Hu, Y. H., Yuan, Z., et al. (2010). Enhanced osteointegration of orthopaedic implant gradient coating composed of bioactive glass and nanohydroxyapatite. J. Mater. Sci. Mater. Med. 21, 2165-2121. doi: 10.1007/s10856-010-4077-6

Yamada, Y., Ueda, M., Naiki, T., Takahashi, M., Hata, K., and Nagasaka, T. (2004). Autogenous injectable bone for regeneration with mesenchymal stem cells and platelet-rich plasma: tissue-engineered bone regeneration. Tissue Eng 10, 955-964. doi: 10.1089/1076327041348284

Zheng, Y., Liu, Y., Zhang, C. M., Zhang, H. Y., Li, W. H., Shi, S., et al. (2009). Stem cells from deciduous tooth repair mandibular defect in swine. J. Dent. Res. 88, 249-254. doi: 10.1177/0022034509333804

Zhou, H., Xiao, C., Wang, Y., Bi, X., Ge, S., and Fan, X. (2011). In vivo efficacy of bone marrow stromal cells coated with beta-tricalcium phosphate for the reconstruction of orbital defects in canines Invest. Invest. Ophthalmol. Vis. Sci. 52, 1735-1741. doi: 10.1167/iovs.10-5988

Zimmermann, W. H., Didié, M., Wasmeier, G. H., Nixdorff, U., Hess, A., Melnychenko, I., Boy, O., et al. (2002). Cardiac grafting of engineered heart tissue in syngenic rats. Circulation 106, I151-I157. doi: 10.1161/01.cir.0000032876.55215.10

Zimmermann, W. H., Melnychenko, I., and Eschenhagen, T. (2004). Engineered heart tissue for regeneration of diseased hearts. Biomaterials 25, 1639-1647. doi: 10.1016/S0142-9612(03)00521-0

Zimmermann, W. H., Melnychenko, I., Wasmeier, G., Didie, M., Naito, H., Nixdorff, U., et al. (2006). Engineered heart tissue grafts improve systolic and diastolic function in infarcted rat hearts. Nat. Med. 12, 452-458. doi: $10.1038 / \mathrm{nm} 1394$

Zmora, S., Glicklis, R., and Cohen, S. (2002). Tailoring the pore architecture in 3-D alginate scaffolds by controlling the freezing regime during fabrication. Biomaterials 23, 4087-4094. doi: 10.1016/S0142-9612(02) 00146-1

Conflict of Interest Statement: The authors declare that the research was conducted in the absence of any commercial or financial relationships that could be construed as a potential conflict of interest.

Copyright (c) 2019 Sharma, Mujawar and Kaushik. This is an open-access article distributed under the terms of the Creative Commons Attribution License (CC BY). The use, distribution or reproduction in other forums is permitted, provided the original author(s) and the copyright owner(s) are credited and that the original publication in this journal is cited, in accordance with accepted academic practice. No use, distribution or reproduction is permitted which does not comply with these terms. 